\title{
手指皮下組織の循環動態に関する研究
}

第 1 報 上肢肢位との関速について

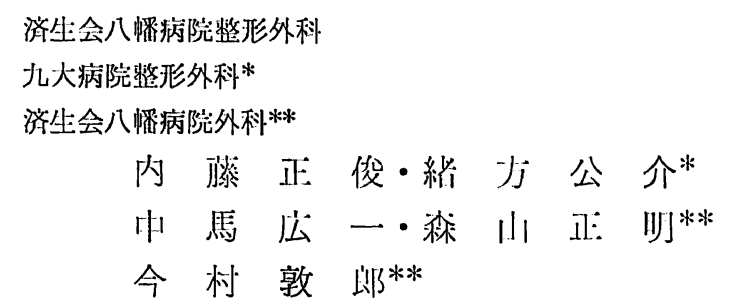

\section{The Acute Effect of Postural Change on Subcutaneous Tissue Blood Flow in the Hand Region}

by

\author{
M. Naito, K. Ogata*, H. Chuman, M. Moriyama**, \\ and A. Imamura** \\ Department of Orthopaedic Surgery,Saiseikai Yahata Hospital \\ *Department of Orthopaedic Surgery, Faculty of Medicine, Kyushu University \\ **Department of Surgery, Saiseikai Yahata Hospital.
}

\begin{abstract}
Acute effect of postural change on human subcutaneous tissue blood flow in the hand region was studied in normal subjects using the hydrogen washout technique, a system which allows repeated determinations of blood flow rate.

Changing from the supine to the upright position caused decrease of the subcutaneous tissue blood flow in the hand region by approximately 46 per cent. Lowering an arm below heart level reduced that subcutaneous tissue blood flow in the hand region. The subcutaneous tissue blood flow was also found to be reduced in the hand region by raising an arm above heart level.

These findings have important implications in the postoperative mangements following hand surgery.
\end{abstract}

緒言

整形外科医が手指の循環障害を伴う疾患を治療する 機会は少なくない，乙れらの疾患に於いて，上肢肢位 の変化によって起てる手部循環動態の変動について知 るこ之は治療上重要であると思われる. 今回，我々は 健康成人を対象として上肢肢位の変化之手部皮下組織 血流量との関連について定量的研究を行なったので報 告する.

\section{対象及び方法}

我々を含めた健康な男性 9 名の有志者を対象とし，
血流量测定に水絭クリアランス法を朋いて何究を行な

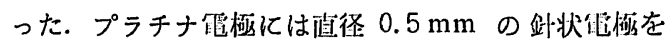
使用し, 先端の約 $2 \mathrm{~mm}$ 以外 epoxy resin により

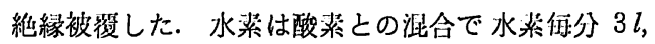
酸素每分 $4 l$ にて罢マスクにより投与した. 右前腕に 不関電極装着後左手背侧第 1 指間部皮下組織にプラチ ナ電極を約 $2 \mathrm{~mm}$ 刺入し，血压をコントロールとし て以下の $6 \supset$ つ肢肢位で手部皮下組織血流量を测定 した. 即ち, 臥位では㕆関節 $0^{\circ}$ 时阅節 $0^{\circ}$ の中间位, 肩関節 $90^{\circ}$ 前方挙上时関節 $90^{\circ}$ 屈曲の離被架国定位, 肩関節 $90^{\circ}$ 前方挙上付関節 $0^{\circ}$ の 3 肢位であり, 立位 では中間位, 时関節 $90^{\circ}$ 届曲の 3 角巾固定位, 原関節 
$180^{\circ}$ 前方挙上村関節 $0^{\circ}$ の 3 肢位であった．測定中及 び测定後何らかの症状を訴たえたものは 1 例むなく 血圧はほぼ一定であった。

\section{結果}

表 1 亿結果を示す. 症例 $1 ， 2 ， 8$ は 3 ないし 4 肢 位でしか手部皮下組織血流量を测定できなかった症例 である. てれらの 3 症例に於いてむ他の症例之同様に 卧位より立位あるいは手部が心歲高位より離れるにつ
れ手部皮下組織血流量が減少する傾向を認めた。

9 症例中乙れらの 3 症例を除外した症 例 $3 ， 4$, $5,6,7,9$ の 6 症例について 検討を加えた（図 $1)$.

肩関節 $0^{\circ}$ 时関節 $0^{\circ}$ の中間位での臥位及び立位の 手部皮下組織血流量はそれぞれ組織 $1 \mathrm{mI}$ 当たり毎分 $0.394 \mathrm{ml}$, 每分 $0.212 \mathrm{ml}$ であり, 立位時の手部皮下 組織血流量は臥位時のそれの約 $54 \%$ であった（図 1).

表 1 種々の肢位に於ける手部皮下組織血流量

表 1 Subcutaneous Tissue Blood Flow Rate in Human Hand ( $\mathrm{ml} / \mathrm{min} / \mathrm{ml}$ )

\begin{tabular}{|c|c|c|c|c|c|c|c|c|}
\hline \multirow[b]{2}{*}{ Case } & \multirow[b]{2}{*}{$\begin{array}{l}\text { Age } \\
\text { (yr.) }\end{array}$} & \multirow[b]{2}{*}{$\begin{array}{c}\text { Body } \\
\text { weight } \\
\text { (kg.) }\end{array}$} & \multicolumn{3}{|c|}{ Supine Position } & \multicolumn{3}{|c|}{ Standing Position } \\
\hline & & & $\begin{array}{c}\text { Shoulder } 0^{\circ} \\
\text { Elbow } 0^{\circ}\end{array}$ & $\begin{array}{l}\text { Shoulder } 90^{\circ} \\
\text { ant. elev., } \\
\text { Elbow } 90^{\circ} \\
\text { flex. }\end{array}$ & $\begin{array}{c}\text { Shoulder } 90^{\circ} \\
\text { ant. elev. } \\
\text { Elbow } 0^{\circ}\end{array}$ & 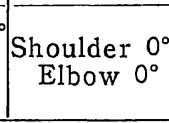 & $\begin{array}{c}\text { Shoulder } 0^{\circ} \\
\text { Elbow } 90^{\circ} \\
\text { flex. }\end{array}$ & $\begin{array}{c}\text { Shoulder } 180^{\circ} \\
\text { ant. elev. } \\
\text { Elbow } 0^{\circ}\end{array}$ \\
\hline $\begin{array}{l}1 \\
2 \\
3 \\
4 \\
5 \\
6 \\
7 \\
8 \\
9\end{array}$ & $\begin{array}{l}31 \\
27 \\
36 \\
26 \\
42 \\
25 \\
34 \\
24 \\
32\end{array}$ & $\begin{array}{l}67 \\
70 \\
60 \\
58 \\
59 \\
67 \\
68 \\
59 \\
70\end{array}$ & $\begin{array}{l}0.630 \\
0.578 \\
0.737 \\
0.277 \\
0.277 \\
0.193 \\
0.347 \\
0.301\end{array}$ & $\begin{array}{l}0.430 \\
0.352 \\
0.396 \\
0.231 \\
0.244 \\
0.117 \\
0.301 \\
0.231\end{array}$ & $\begin{array}{l}0.283 \\
0.385 \\
0.144 \\
0.154 \\
0.131 \\
0.257 \\
0.187\end{array}$ & $\begin{array}{l}0.693 \\
0.315 \\
0.283 \\
0.462 \\
0.154 \\
0.139 \\
0.131 \\
0.141 \\
0.103\end{array}$ & $\begin{array}{l}0.770 \\
0.322 \\
0.693 \\
0.128 \\
0.224 \\
0.122 \\
0.117\end{array}$ & $\begin{array}{l}0.533 \\
0.365 \\
0.239 \\
0.082 \\
0.169 \\
0.042 \\
0.131\end{array}$ \\
\hline \multicolumn{3}{|c|}{$\begin{array}{l}\text { Mean } \\
\text { Standard Error }\end{array}$} & $\begin{array}{l}0.418 \\
0.025\end{array}$ & $\begin{array}{l}0.288 \\
0.013\end{array}$ & $\begin{array}{l}0.220 \\
0.013\end{array}$ & $\begin{array}{l}0.269 \\
0.022\end{array}$ & $\begin{array}{l}0.339 \\
0.040\end{array}$ & $\begin{array}{l}0.223 \\
0.025\end{array}$ \\
\hline
\end{tabular}

issue Blood Flow in Human Hand

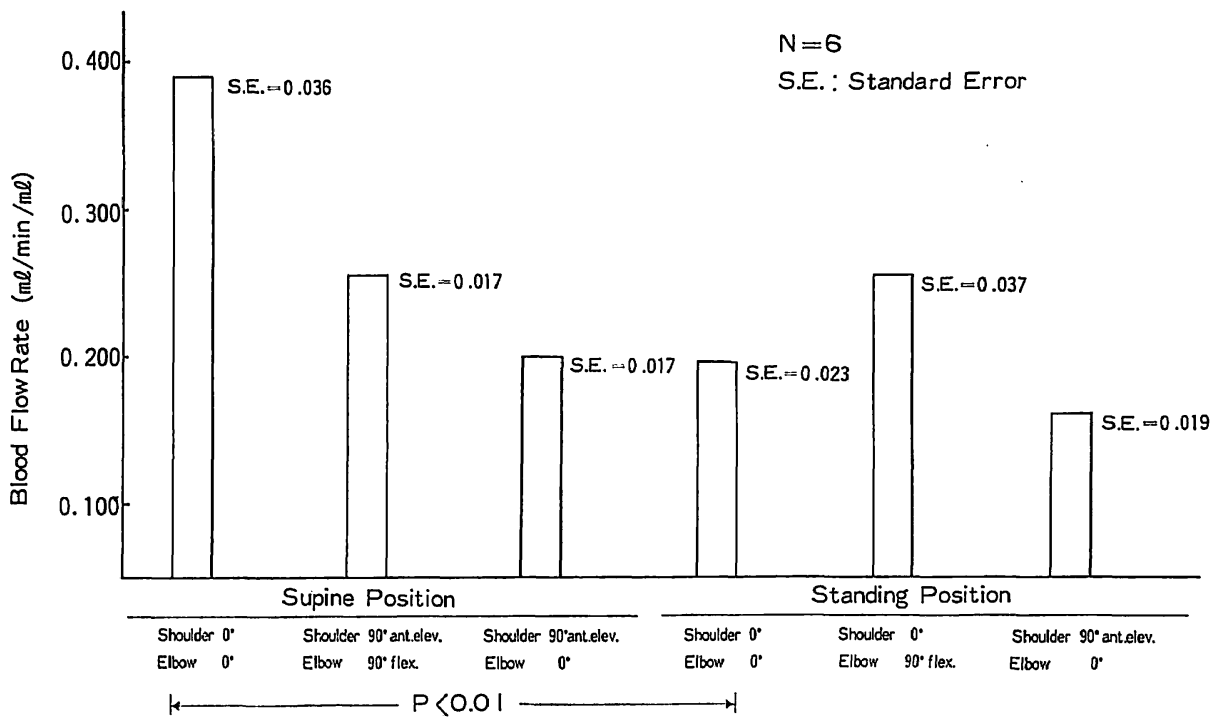

図 1 肢位の变化が手部皮下組織血流量に及ほす影櫭 
臥位の 3 肢位では中間位に於いて，立位の 3 肢位で は肩関節 $0^{\circ}$ 肘関節 $90^{\circ}$ 屆曲の三角巾固定位に於いて 手部皮下組織血流量は最大であった，又，臥位及び立 位に於いて，手部皮下組織血流量は心歲高位上り離れ るにつれて減少する傾向が認められた（図 1).

\section{考察}

1. 水素クリアランス法の臨床的研究への応用につ いて

現在臨床で使用されいる血流测定法には大別して非 観血的測定法と観血的測定法との 2 種類がある. 非観 血的測定法の代表として超音波ドプラ血流計を用いる 方法") があるが，本法で血流量の絶対值を求めること は不可能である. 観血的測定法の代表として電磁血流 計を用いる方法があるが，本法は求める組織を露出せ ねばならず操作が煩雑及び侵裂が大であるという欠点 を有する。

一方，水素クリアランス法は電極の刺入による組織 の損傷という欠点を有する。しかし，本研究の如く細 い針状電極を用いた場合組織の損傷は怪微であり，電 極刺入固定後繰り返し容易に血流量を測定できる利点 を持つ本法は臨床上貫重な検査法となり得ると考えら れ4)5, 我々は测定器具一式を携帯用として循環動態 亿関する臨床的研究へ本法を応用している.

2. 上肢肢位の変化が手部皮下組織血流量に及ぼす 影響について

手の外科特に切断指再接着等に於いて，肢位の変化 が手指の循環動態に如何なる変化を及ぼすかというと とを知るととは術後治演過程上重要であると考えら れ，本研究を施行した.

同一肢位（肩関節 $0^{\circ}$ 时関節 $0^{\circ}$ の中間位）で臥位 から立位になるととにより，手部皮下組織血流量は約 $46 \%$ 減少した. 又，臥位及び立位でのそれぞれの 3 肢 位について検討を加えると，手部皮下組織血流量は必 臓高位より離れるにつれ減少する傾向が認められた。 乙の肢位の変化之併に末梢組織血流量が変動する原因 として, local venoarteriolar reflex, baroreceptor の関与等が考えられる(1) 3).

本研究は健康成人について行なったすのであり，与 後晴に臨床例についてあ検討を加えていく予定であ る.
結語

1. 健康人を対象として水䋕クリアランス法を応用 し，手部皮下組織血流聂と上肢肢位との関速について 検討を加えた.

2. 手部皮下組織血流照は队位中間位の㭙最大であ り，立位及び心陶高位より手部が離れるにつれ娍少す る傾向が認められた。

\section{参考 文 献}

1) Henriksen, O.: Local sympathetic reflex mechanism in regulation of blood flow in human subcutaneous adipose tissue. Acta physiol. scand. suppl. 450. 1977.

2) Henriksen, O., et al.: Local regulation of blood flow in peripheral tissue. Acta Chir. Scand. 502: 63-74, 1980.

3) Hilsted, J.: Decreased sympathetic vasomotor tone in diabetic orthostatic hypotension. Diabetes 28: 970-970, 1079.

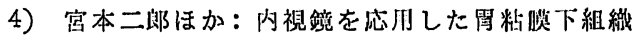
血流湦の測定 Progress of Digestive Endoscopy, 14:57-61, 1979.

5）緒方公介：水翡クリアランス法の橴形外科㑇域 への応用, 日胫会誌, 55: 769-777，1981.

6)解㴊康彦ほか：末梢血流榆知のためのドプラテ クニック, 臨外, 36:1271-1279, 1981.

\section{質 問 大村市立病院整形外科 下染 剛炏}

手指皮下組㵶の wash out process を $\mathrm{A} ・ \mathrm{e}^{\mathrm{kt}}$ だ けの 1 component だけで一意性に裴現できます か.

\section{質 問 那須 吉郎}

(1) 手背皮䐗温は環境温度に大きく左石される. サ 一モグラフィーで観祭すると通常の着农では低くでは 安定しません，指腹部で皮下 $5 \mathrm{~mm}$ の㳭部温と婊面

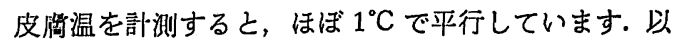

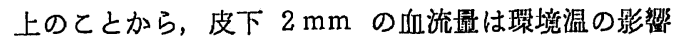
あかなり受けると考えますが，ての点に関してどうで しょうか. また先生の実験された㭙の室温条件はどの ようでしたでしょうか. 